\title{
Project Evaluation Based On Sharia Construction Management and Green Building Principles
}

\author{
Agung Sedayu ${ }^{1}$ \\ ${ }^{1}$ Department of Architecture Engineering, Faculty of Science and Technology, Maulana Malik Ibrahim State Islamic \\ University, Malang \\ Email: uinsedayu@gmail.com
}

\begin{abstract}
This current Indonesia has many problems in project development that caused many conflicts. Housing projects problem for the community needs to get the handling and solving. The habits for project developers to obtain maximum profit but much harm to users need to be repaired and straightened. The purpose of this research to evaluate the quality of services procurement projects in Griya Amorf Sawojajar Malang, East Java with an overview of the principles of Islamic Sharia Management and Sustainable and Green Building. This research use Islamic Sharia caused this principles can be used in many problems that has relation with social-culture aspects. The principles will be adapted to cosnrtuction management. At this current, many project construction cause more complex environmental damage. The destruction in enviromnetal can be solved and evaluated by using green building principles. Green building is derivied from building sustainable produce bulding that environmental friendly. This research methods are Importance Performance Analysis (IPA) and Quality Function Deployment (QFD). The IPA results obtained 12 factors with the highest score of importance is the construction process on time schedule of the project. The QFD results obtained 17 technical response with the highest score is the service with sharia system: payment, contract, agreement, and information clearly and honestly.
\end{abstract}

Keywords: housing project, Islamic sharia, construction management, green building

\section{INTRODUCTION}

\section{A. Background}

Development of construction projects in Indonesia, followed by a wide range of issues relating to the construction of physical facilities, especially the building. These problems lead to conflicts both among humans and the environment.

The emergence of many affiliated contracting company being a developer in the field of property add competition to encourage firms to compete to increase its presence in the construction project. The construction company (contractor) do a lot of innovations and breakthroughs in managing the organization of the company, began to managerial offices, public relations, marketing, to implementation and physical implementation in the field (Sedayu, 2010: 47). The competitions often add a lot of issues that cause detriment to the client. Entrepreneurs do construction financial management often Islamic law, in which the construction projects in favor of the contractor but the disadvantage for the customer. Management used is not based on sharia, but many liberal and capitalistic-based. As is known, the economic system that dominates in Indonesia is a liberal and capitalistic economic system. Revrisond Baswir describes the position of a company's earnings report, which is based accounting capitalistic. The existence of labor will determine the position of the profit or loss of the company, but the opposite is true, labor costs are treated as expenses and grouped together with the accounts of other production cost price (Siddiqi, 1991: 87). The degree of inequality between leaders and employees only occurs in capitalist and socialist economy, as the Prophet warned in a hadith that the waiter we are our brothers (Abusinn, 2008).
Procurement issues for the public housing projects need to get treatment and solution. Management systems and existing services should refer to the principles of Islamic law and according to the principles of Green Building.

\section{B. Objective}

This study aimed to evaluate the performance and service quality of the developer/contractor in the construction project held in Griya Amorf Sawojajar Malang City, East Java with an overview of Islamic law and the Green Building aspects.

The constraint of this study on the phase of construction and technical requirements relating to the project. Overview of the study, the principles of green building and sharia construction management.

\section{Literature Review}

1. The Conceptual Framework of Facility Performance The conceptual framework of this study refers to the Performance Based Design of Buildings (PeBBu), Final Domain Report CIBdf (Spekkink, 2005) which gives the concept of service quality of a physical facilities such as buildings based on performance by considering the balance between the technical aspects of the building includes major facilities and support with the user needs. There is compatibility between the technical aspects and functional aspects by the user.

\section{Green Building Principles}

The building comfort can apply green building. The green building planning and design should have attention to spatial organization and building materials. In addition, social, cultural, and historical aspect becomes a very important element to take part applied in the building design. 
To anticipate any disruption to the building, it can be applied that green building concept is a concept to minimize impacts on natural and human environment (Sedayu, 2015). Green Building considers many principles include:
a. Conserving energy
b. Working with climate
c. Minimizing new resources
d. Respect for user
e. Respect for site
f. Holism

Green building principles includes,

a. Sustainable

Which means building that apply green building will survive and has function, consistent with the concept that friendly to the nature without changes and damaging the surrounding nature.

b. Earthfriendly

Green building has a friendly character to environment, energy, and other aspects.

c. High performance building

Green building concept is "High performance building" that minimizes the use of energy derived from nature (Energy of nature) and combined with high technology (High technology performance). For example:

1) Use solar cell and wind power in hybrid technology to apply natural energy.

2) Use recycled materials to apply for the building

3) Use construction, physical form, and the facade of the building to support the green building concept.

3. Application of Sharia Principles in Construction Services

1). Sharia Management

According K.H. Didin Hafidhuddin (2003), the sharia management is a behavior associated with the iman and tauhid values. If any people behavior involved in an activity based on the tauhid value, it is expected behavior must always be aware of the existence of Allah swt which will record every deed, both good and bad. This differs from conventional management that is completely unrelated even apart from the tauhid values.

According to Ahmad Ibrahim Abu Sinn (2006) among the characteristics that distinguish the management theory of Islam with other theories is the concentration of the Islamic theory against all the variables that influence on management activities within and outside the organization, and the relationship of individual behavior towards the social factors that influence.

\section{2).Sharia Management of Project Construction}

Sharia construction management apply 5 principles (see Figure 1):

a. Kinship

This principle has similarly with the principles of worshipers in the Islamic conception. The construction project involves many parties and stakeholders that interact in a system of project construction.

b. Openness
Project management system that used is open management system. Aspects of openness, honesty, and transparency is very important in construction projects.

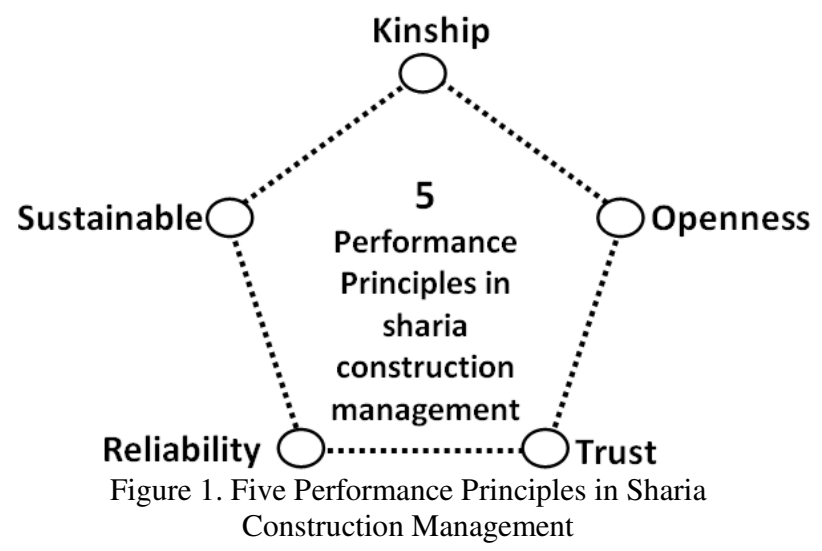

c. Trust

Establishment of openness between the parties interested that involved in the project will bring a sense of trust between the two sides, because the openness of the management system used to implement and realize a work or construction project is based on honesty.

d. Reliability

The principle of reliability include the timeliness of construction work in accordance with the plans and agreements, precision design and results of the implementation with material specification set, the accuracy of the maximum work, the results are balanced with the cost, and service to all the grievances and complaints of the users.

e. Sustainable

The construction is expected to be consistent and sustainable. Consistency is management based on the Islamic sharia with the hope and the blessings of Allah swt.

D. The Previous Researches

This research was supported by several studies and previous research. Table 1 shows the previous study. 
The Third International Conference on Civil Engineering Research (ICCER)

August $1^{\text {st }}-2^{\text {nd }}$ 2017, Surabaya - Indonesia

Table 1. The Previous Researches

\begin{tabular}{|c|c|c|c|c|c|}
\hline Number & Researcher & Year & Research Variables & Method & $\begin{array}{l}\text { The Relationship } \\
\text { with This Research }\end{array}$ \\
\hline 1 & Nuryani & 2006 & $\begin{array}{l}\text { Adminstration, organization, payment, land acqutition, facility procurement, and housing } \\
\text { built mecanism }\end{array}$ & $\begin{array}{l}\text { Integrity between qualitative } \\
\text { and quantitative analysis }\end{array}$ & $\begin{array}{l}\text { Variable and method to } \\
\text { be adapted and developed }\end{array}$ \\
\hline 2 & Hardiman & 2006 & Site condition, building materials, utilities & - Conceptual study & $\begin{array}{l}\text { Variable to be developed } \\
\text { and teory to be refered }\end{array}$ \\
\hline 3 & Andriati & 2007 & Reliability, durability, and environment controlling & $\begin{array}{l}\text { - Survey and interview } \\
\text { - Discussion by expert }\end{array}$ & $\begin{array}{l}\text { Variable to be developed } \\
\text { and teory to be refered }\end{array}$ \\
\hline 4 & Herina & 2007 & Building element, building quality, improvement, and user comfort & $\begin{array}{l}\text { - Survey and interview } \\
\text { - Discussion by expert }\end{array}$ & $\begin{array}{l}\text { Variable to be developed } \\
\text { and teory to be refered }\end{array}$ \\
\hline 5 & Sedayu & 2010 & Budget Analysis for project and sharia construction management & $\begin{array}{l}\text { - Conceptual study } \\
\text { - Contextual study }\end{array}$ & $\begin{array}{l}\text { Teory to be adapted and } \\
\text { research data to be developed }\end{array}$ \\
\hline 6 & Wulandari & 2010 & $\begin{array}{l}\text { The understanding of company leaders, stakeholders principles, The similarity of } \\
\text { company leaders, Tranparecy principles, corporation accountability }\end{array}$ & $\begin{array}{l}\text { - Documentation } \\
\text { - Alternative approach }\end{array}$ & $\begin{array}{l}\text { Variable and method to be adapted } \\
\text { and developed,a, also teory adapted }\end{array}$ \\
\hline 7 & Ambrosius & 2011 & $\begin{array}{l}\text { Financial criteria, personel, tools, working experience, quality management, work } \\
\text { safety, time, cost, and quality }\end{array}$ & $\begin{array}{l}\text { - Survey } \\
\text { - Linear regression analysis }\end{array}$ & $\begin{array}{l}\text { Variable and method to } \\
\text { be adapted and developed }\end{array}$ \\
\hline 8 & Mardiansyah & 2012 & Location, raining, and drainage system & $\begin{array}{l}\text { - Survey } \\
\text { - Decsriptive quatitative }\end{array}$ & Variable to be developed \\
\hline 9 & Priyo & 2013 & Cost and technically aspect & $\begin{array}{l}\text { - Lost system } \\
\text { - Merit Point System }\end{array}$ & $\begin{array}{l}\text { Teory to be refered } \\
\text { and developed }\end{array}$ \\
\hline 10 & Huda & 2013 & $\begin{array}{l}\text { Appropriate Site Development, Energy Efficiency and Refrigerant, Water Conservation, } \\
\text { Material Resources and Cycle, dan Indoor Air Health and Comfort }\end{array}$ & $\begin{array}{l}\text { - Field measurement } \\
\text { - Qualitative and quantitative } \\
\text { - Greenship standard ranking }\end{array}$ & $\begin{array}{l}\text { Variable and method to } \\
\text { be adapted and developed }\end{array}$ \\
\hline 11 & Syahrozi & 2013 & Land use, form and fasade of building, and air conditoning & $\begin{array}{l}\text { - Documentation } \\
\text { - Optimation and modeling }\end{array}$ & $\begin{array}{l}\text { Variable and method to } \\
\text { be used and developed }\end{array}$ \\
\hline 12 & Ervianto & 2013 & $\begin{array}{l}\text { Environment and Water, Access and Equity, Construction Activities, Materials and } \\
\text { Resources, dan Pavement Technologies }\end{array}$ & $\begin{array}{l}\text { - Rating Greenroad } \\
\text { - Invest }\end{array}$ & $\begin{array}{l}\text { - Variable to be developed } \\
\text { - Teory to be used }\end{array}$ \\
\hline 13 & Komalasari & 2014 & $\begin{array}{l}\text { Energy Efficiency Measure, Natural and artificial Lighting, Ventilation, Climate Change } \\
\text { Impact, dan Air condition system }\end{array}$ & $\begin{array}{l}\text { - Comparasion study } \\
\text { - Modeling by using } \\
\text { software } \\
\text { - Field measurement }\end{array}$ & $\begin{array}{l}\text { - Variable to be developed } \\
\text { - and teory to be refered } \\
\text { - Use the research step } \\
\text { - and method }\end{array}$ \\
\hline 14 & Muzammil & 2014 & Flood intensity, soil water quality, flood area, and soil type & Survey and field application & Method to be adapted \\
\hline 15 & Sedayu & 2015 & $\begin{array}{l}\text { Security, Safety and Health, Responsiveness of management institution, Utility building } \\
\text { performance, Architectural aesthetics, convenience and affordability, Transport } \\
\text { reliability, Building durability, Frequency and density, Comfort and regularity, } \\
\text { availability and capacity of public facilities, and application of environmental-friendly } \\
\text { concept }\end{array}$ & $\begin{array}{l}\text { - Survey } \\
\text { - Statistic Descriptive }\end{array}$ & $\begin{array}{l}\text { Variable to be adapted } \\
\text { and developed }\end{array}$ \\
\hline
\end{tabular}




\section{METHOD}

The method and analysis step contain of:

1.Literature review and previous research

This step to deteminate instrument for preliminary survei

2.Voice of user arrangement

Collecting voice of user by preliminary survei. Measurement scale in preliminary survei include:

- $1=$ not required

- 2 = less required

- 3 = quite required

- $4=$ required

- 5 = very required

3. Voice of user developed become continuation instrument.

Continuation instrument to be distributed to 30 respondents for test. Beside that, to know validity should use validity test. Validity test is used to know the validity of questioner to respondents. The number of respondents are 30 persons (Sugiyono, 2009). This test as correlation test by use product moment from Pearson equation:

$$
r_{x y}=\frac{N \sum X Y-\left(\sum X\right)\left(\sum Y\right)}{\sqrt{\left.\left[\left\{N X^{2}-\left(\sum X\right)^{2}\right\}\left(N \sum Y^{2}\right)-\left(\sum Y\right)^{2}\right\}\right]}}
$$

Where :

$\mathrm{r}_{\mathrm{xy}}=$ Correlation coeficient for all items

$\mathrm{X}=$ Respondents score for each item

Table 2. Measerument scale in research instrument

\begin{tabular}{|c|c|c|c|}
\hline Variable & User Importance (TK) & User Satisafaction (KP) & User Expectation (HP) \\
\hline Measurement scale & $\begin{array}{l}1=\text { Not important } \\
2=\text { Less important } \\
3=\text { Quite important } \\
4=\text { Important } \\
5=\text { Very important }\end{array}$ & $\begin{array}{l}1=\text { Not satisfactory } \\
2=\text { Less satisfactory } \\
3=\text { Quite satisfactory } \\
4=\text { Satisfactory } \\
5=\text { Very satisfactory }\end{array}$ & $\begin{array}{l}1=\text { Not expected } \\
2=\text { Less expected } \\
3=\text { Quite expected } \\
4=\text { Expected } \\
5=\text { Very expected }\end{array}$ \\
\hline
\end{tabular}

\section{Continuation Survey \\ Continuation Survey by distributing continuation} intrument to respondents that house user or owner.

5. Importances Performance Analysis

This analysis is intended to get user importance to service factors. In principle, IPA combines dimensional measurements to the expectations and importance two grids (see IPA diagram in Figure 2), then both dimensions were plotted into it. Importance value is plotted as the vertical axis while the expected value as a diagonal axis by using the mean value contained in importance and expectation dimension as the center line cutting. The diagram consists of four-quadrant that shows level of importance to service factors. IPA is used to get the importance of customer to service factors. The level of importance is described in the importance diagram that is divided into four quadrants (Figure 2) with description as follows,

a. Quadrant A, the area that contains the factors are considered important by customers but not as expected (levels of customer satisfaction are still very low). In this area the management institution perform improvements continuously in order to increase performance in this quadrant.

b. Quadrant B, the area that contains the factors is considered important by customers and the factors
$\mathrm{Y}=$ Score total for each respondents in all items $\Sigma X=$ Number of score in distribution $\mathrm{X}$ $\Sigma Y=$ Number of score in distribution $\mathrm{Y}$ $\Sigma X^{2}=$ Number of square of each score $X$ $\Sigma Y^{2}=$ Number of square of each score $Y$ $\mathrm{N}=$ Number of subjects

In this research, an instrument is difined has strong correlation if the correlation value more bigger than 0,6 (Sugiyono, 2009). Reliability test aim to know that data collector can show the level of accuracy, stability, and consistency in define phenomena in different time. To examine the internal consistency by using consistency coefficient (Alpha Cronbach). Alpha Cronbach eaquation that used in this reliability test as follows:

$r_{1}=\left[\begin{array}{l}k \\ k-1\end{array}\right]\left[\begin{array}{l}1-\sum \sigma b^{2} \\ \sigma \cdot t^{2}\end{array}\right]$

Where :

$\mathrm{r}_{1} \quad=$ Instrument consistency

$\mathrm{k}=$ Number of question iteml

$\Sigma \sigma b^{2}=$ Number of variance

$\sigma \mathrm{b}^{2}=$ Total variance

The instrument will be reliable if the consistency coefficient has value above 0,60 (Sugiyono, 2009). The both test include validity and reliability test by using SPSS 20. are assumed in accordance with the perceived so the level of satisfaction is high.

c. Quadrant C, the area that is contains factors are considered less important by the customer and in fact have less special performance.

d. Quadrant D, the area that contains the factors are considered less important by the customer and assumed excessive.

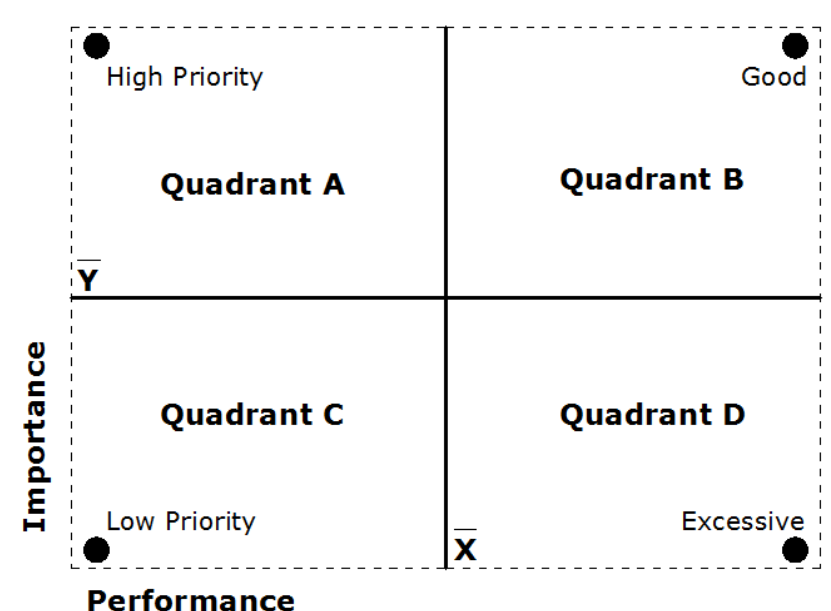

Figure 2. Importance Classification Diagram Source: Wijaya, 2011 


\section{Quality Function Deployment}

Quality Function Deployment (QFD) is method to determine priorities and targets to improve the quality of terminals service according to customer needs by making house of quality (HoQ) that is part QFD analysis as shown in Figure 3.

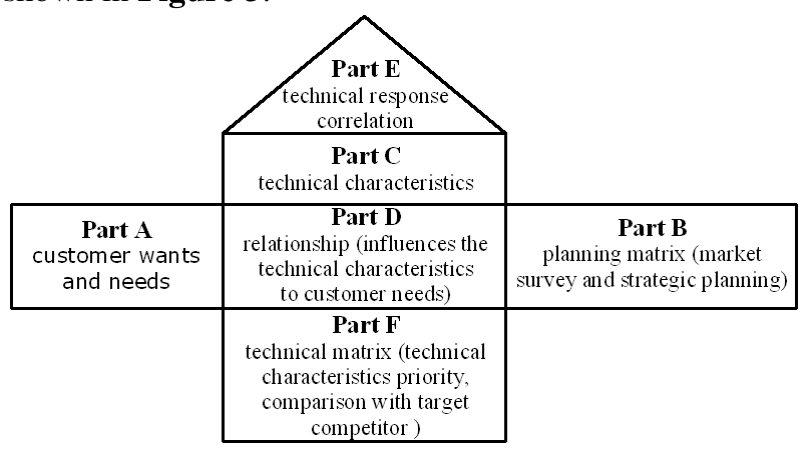

Figure 3. House of Quality in QFD

Source : Rauf, 2002

The reason of using this sampling type, because the population components have heterogeneous characteristic, and the heterogeneity have significance to the achievement of the research goals. The determination of this research sample is sought by the Bernoulli equation: $\mathrm{N} \geq \frac{\left(\mathrm{Z}_{\mathrm{a} / 2}\right)^{2} \mathrm{p} \cdot \mathrm{q}}{\mathrm{e}^{2}}$, so that become

$$
\mathrm{N} \geq \frac{(1,96)^{2} \cdot 0,95 \cdot 0,05}{(0,05)^{2}} \rightarrow \mathrm{N} \geq 72,99 \approx 73
$$

Where, $\mathrm{N}=$ amount of minimum sample; $\mathrm{Z}=$ value of normal distribution; $\mathrm{e}=$ level of error; $\mathrm{p}=$ proportion of questionnaires that are assumed true; $\mathrm{q}=$ proportion of questionnaire that are assumed false. Value is assumed true equal to $95 \%$, and then questionnaires that are assumed wrong equal to $5 \%$.To avoid lacking of data because of mistake of filling or the questionnaires are not return, the number of respondents to be used by 100 persons.

Stages in QFD analysis include:

a) Customer Satisfaction Performance: user assessment about how well the management institution or employees give services to the customer. Weight Average Performance $=$

\section{$\sum$ Performance Weight \\ Number of Respondent \\ $=\frac{\sum \text { (Level of satisfaction) } \mathrm{x} \text { Number of respondent }}{\text { Number of respondent }}$}

Customer Expected Performance: part of the Customer expected performance, Weight Average Performance $=$

$\frac{\sum \text { Expected Performance Weight }}{\text { Number of Respondent }}$

$=\underline{\sum}$ (Level of expected performance) $\mathrm{x}$ Number of respondent Number of respondent b) Negative gap indicates the problems faced by the management institution so that the necessary corrective action in order to improve the quality of services.

c) Goal: how much the level of expected satisfaction performance can be achieved by the management institution or employees to meet every customer needs.

d) Improvement Ratio (IR): a parameter of efforts that should be done by the management institution or employees to improve the quality of services. IR formula:IR $=\frac{\text { Goal }}{\text { Customer SatisfactionPerformance }}$

e) Sales Point is determined by the management institution, this value reflects the ability to sell services and products based on how well each user or customer wishes can be fulfilled. Scale for Sales Point is:

- 1.0 Indicates no selling point

- 1.2 Indicates medium selling point

- 1.5 Indicates strong selling point

f) Raw Weight contains the calculation values from data and decisions were made during the preparation of the planning matrix. Value of raw weight for each customer needs is:

Raw Weight $=$ (Importance to Customer) $\mathrm{x}$ (Improvement Ratio) x (Sales Point)

g) Normalized Raw Height contains the Raw Weight value that is scaled in design between 0 to 1 or expressed in percentage. Normalized Raw Height $=$ Raw Weight

Raw Weight Total

h) Technical Response is discussions result between researchers with management employees that should have been by public transport terminal according to customer input.

i) Relationships and priorities matrix will be described how the technical response influenced the handling and controlling what the customer needs and customer satisfaction performance.

Table 3. The relationship matrix symbols

\begin{tabular}{lcc}
\hline Definition & Symbol & Numerical value \\
\hline No relationship & Empty & 0 \\
Weak relationship & 1 \\
Moderate Relationship & & 3 \\
Strong Relationship & & 9
\end{tabular}

Source : Rauf, 2002

The priority value describes the contribution from technical responses to customer fulfillment. Contribution (cont) $=\Sigma$ Normalized Raw Height $\mathrm{x}$ Relationship Matrix Numerical Value

Contribution value: priority and technical responses in scale 0 to 1 that indicates the percentage to be obtained from:

Normalized contribution $(\mathrm{NC})=\frac{\text { Contribution }}{\text { Total Contribution }}$ 
Where cont $=$ contribution

j) Own Performance (OP) is calculated with formula :

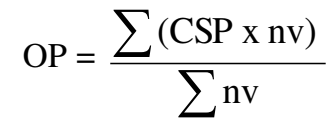

Where,
$\mathrm{CSP}=$ customer satisfaction performance

$\mathrm{nv}=$ numerical value

k) Arrange and make affinity diagram that describe the classification of a terminal service attributes.

Table 4. Services Factor Classification

\begin{tabular}{clcc}
\hline Notation & \multicolumn{1}{c}{ Service Factors } & Mean & Rank \\
\hline $\mathrm{P}_{1}$ & $\begin{array}{l}\text { Assurance in aggreement, payment, design, document, force majure condition, building } \\
\text { destruction, interuption and intimidation }\end{array}$ & 4,088 \\
$\mathrm{P}_{2}$ & $\begin{array}{l}\text { Responsiveness and reliability of developers in providing attention, to solve many } \\
\text { problems, good in service and communication, know all information, polite and } \\
\text { friendly, and construction process finish on time }\end{array}$ & 4,125 & 1 \\
& $\begin{array}{l}\text { Performance of facility and utiliy at housing and region, and performance of } \\
\text { construction and non construction materials }\end{array}$ & 3,769 \\
$\mathrm{P}_{3}$ & $\begin{array}{l}\text { Aesthetics suitable with design, cost, and material specification that is determinated and } \\
\text { agreed }\end{array}$ & 3,743 \\
$\mathrm{P}_{4}$ & $\begin{array}{l}\text { Easiness in information, inspection and evaluation, service, coordination with } \\
\text { developers, construction company, and banking }\end{array}$ & 3,755 \\
$\mathrm{P}_{5}$ & $\begin{array}{l}\text { Durability in construction and non-construction material and material specication } \\
\text { suitable with criteria }\end{array}$ & 3,870 \\
$\mathrm{P}_{6}$ & $\begin{array}{l}\text { Eco-friendly in design, material, alternative energy from wind and solar cell, no } \\
\text { negative area or space, natural lighting and air circulation, orientation, and spatial } \\
\text { organization }\end{array}$ & 3,811 \\
$\mathrm{P}_{7}$ & $\begin{array}{l}\text { Islamic Design in women and men spactial separation, toilet orientation and location, } \\
\text { building material, and has prayer place }\end{array}$ & 5 \\
$\mathrm{P}_{8}$ & 3,922
\end{tabular}

\section{RESULTS AND DISCUSSION}

\section{A. Voice of User Collecting Result}

Preliminary survey result to 30 respondents (house owner) is shown in Table 4. The eight service factors contain of Assurance, Responsibility and Reliability, Performance, Aesthetics, Easiness, Durability,Ecofriendly, and Islamic Design. From Table 4 shown that factor Responsibility and Reliability $\left(\mathrm{P}_{2}\right)$ has high score in requirement level, while Aesthetics $\left(\mathrm{P}_{4}\right)$ has low score.
B.The result of validity and reliability test

An instrument correlates strongly when the correlation above the value of 0.6 (Sugiyono, 2009), so that the instrument is valid. To rate the reliability of the instrument with the provision that if the coefficient alpha value (Cronbach alpha coefficient) above the value of 0.60 (Sugiyono, 2009), the instrument called reliable. The validity and reliability test result of the instrument are shown in Table 5. The testing process performed with SPSS 20.0. For purposes of analysis necessary research variables are classified 3 User Importance Level (TK), User Satisfaction (KP), and User Expectation (HP).

Table 5. Validity and Reliability Test Result

\begin{tabular}{clccc}
\hline Number & Research Variables & $\begin{array}{c}\text { Validity Test } \\
\text { (Correlation Value) }\end{array}$ & $\begin{array}{c}\text { Reliability Test } \\
\text { (alpha value) }\end{array}$ & Decision \\
\hline 1 & Importance Level (TK) & All items $>0,6$ & $0,965(>0,6)$ & Valid and Reliable \\
2 & User Satisfaction (KP) & All items $>0,6$ & $0,972(>0,6)$ & Valid and Reliable \\
3 & User Expectation (HP) & All items $>0,6$ & $0,942(>0,6)$ & Valid and Reliable \\
\hline
\end{tabular}

From Table 5, it shows that the results of validity and reliability of the instrument is valid and reliable, making it feasible and meets the requirements for analysis and subsequent testing.

\section{C.Description Analysis}

Description analysis to provide a global overview of research results. Frequency description result of service factors in the three variables are presented in Table 6 , while Figure 6-8 presents an overview of the frequency graph. Shown in Table 5 and Figure 5, that the importance level (TK) has level in very important (scale of 4), while the User Satisfaction (KP) level is satisfactory (scale 3). For User expectation (HP) level is expected (scale of 4 ). 
Table 6. Frequency descriptive of research variables

\begin{tabular}{|c|c|c|c|c|c|c|c|c|c|c|c|}
\hline \multirow{3}{*}{ Variable } & \multirow{3}{*}{ Mean } & \multicolumn{10}{|c|}{ Measurement Scale } \\
\hline & & \multicolumn{2}{|c|}{5} & \multicolumn{2}{|c|}{4} & \multicolumn{2}{|c|}{3} & \multicolumn{2}{|c|}{2} & \multicolumn{2}{|c|}{1} \\
\hline & & Freq & $\%$ & Freq & $\%$ & Freq & $\%$ & Freq & $\%$ & Freq & $\%$ \\
\hline TK & 3,946 & 458 & $33,93 \%$ & 605 & $44,81 \%$ & 117 & $8,67 \%$ & 96 & $7,11 \%$ & 74 & $5,48 \%$ \\
\hline $\mathrm{KP}$ & 3,490 & 311 & $23,04 \%$ & 344 & $25,48 \%$ & 475 & $35,19 \%$ & 135 & $10,00 \%$ & 85 & $6,30 \%$ \\
\hline HP & 4,047 & 455 & $33,70 \%$ & 667 & $49,41 \%$ & 108 & $8,00 \%$ & 76 & $5,63 \%$ & 44 & $3,26 \%$ \\
\hline
\end{tabular}

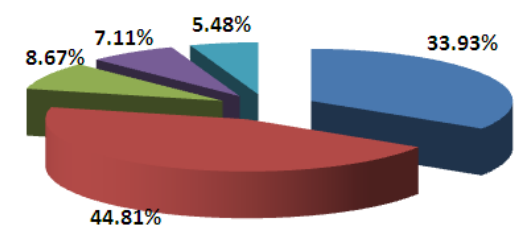

$5 \square 4 \square 3 \square 2 \square 1$

Figure 6. Graph for importance level frequency (TK)

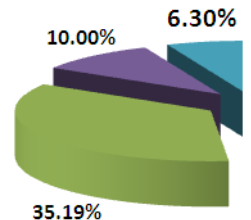

$5 \square 4 \square 3 \square 2 \square 1$

Figure 7. Graph for user satisfaction frequency $(\mathrm{KP})$

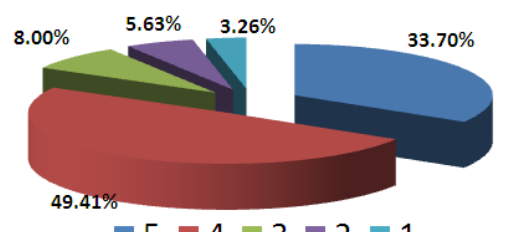

$\square \square 4 \square 3 \square 2 \square 1$

Figure 8. Graph for user expectation (HP)
D.Importance Performance Analysis Result

The eight service factors called the main factors further developed into 45 details the house procurement service factors. The result of the calculation of the value of the mean score of the 45 service factors are presented in Table 7, which includes User Satisfaction (KP) and User Important Level (TK). This is calculated from the continuation survey from 100 respondents.

Table 7. The Importance Level and User Satisfaction Score

\begin{tabular}{|c|c|c|c|}
\hline No & Detailed Performance Factors & $\mathrm{KP}$ & TK \\
\hline 1 & Clarity in contract and agreement that honest, serious benefits, and sharia-compliant & 3,603 & 3,931 \\
\hline 2 & Payment system as sharia can be through Islamic banking & 3,630 & 3,947 \\
\hline 3 & Determine the design and specification of building houses & 3,952 & 3,802 \\
\hline 4 & Completeness and clarity of housing procurement documents & 3,881 & 3,860 \\
\hline 5 & Clarity protection on the condition of force majeure & 3,585 & 3,926 \\
\hline 6 & Service protection to avoid building damage after construction finished & 3,614 & 3,866 \\
\hline 7 & Free from intimidation, harassment. and threats & 3,819 & 3,750 \\
\hline 8 & Developers are paying attention to all client complaints & 3,714 & 3,908 \\
\hline 9 & Developer responsive to client problems & 3,729 & 3,868 \\
\hline 10 & Developers polite and friendly in serving & 3,891 & 3,849 \\
\hline 11 & Developers provide clear and honest information & 3,874 & 3,774 \\
\hline 12 & Developers understand all information & 3,926 & 3,817 \\
\hline 13 & Services in accordance with the clients needs & 3,819 & 3,729 \\
\hline 14 & The construction process on time as scheduled projects & 3,498 & 4,074 \\
\hline 15 & Reliability in service throughout the house procurement activities & 3,565 & 3,967 \\
\hline 16 & The functioning of house facilities and utilities & 3,890 & 3,865 \\
\hline 17 & The functioning of the housing area facilities and utilities & 4,050 & 3,902 \\
\hline 18 & Good performance of construction and non-construction materials & 3,648 & 3,933 \\
\hline 19 & in accordance with the required design items & 3,870 & 3,745 \\
\hline 20 & Building aesthetics in accordance with the payment & 3,848 & 3,780 \\
\hline 21 & Building aesthetics in accordance with the building materials specifications & 3,990 & 3,812 \\
\hline 22 & Easy to obtain the whole house procurement information & 3,776 & 3,766 \\
\hline 23 & Easy to conducting inspections and evaluation of construction & 3,900 & 3,858 \\
\hline 24 & Easy of getting care during and after construction & 3,842 & 3,817 \\
\hline 25 & Easy to coordinate with the developer & 3,866 & 3,711 \\
\hline 26 & Easy to coordinate with the contractor & 3,730 & 3,925 \\
\hline 27 & Easy to coordinate with the banks & 3,825 & 3,766 \\
\hline 28 & Durability of construction and non construction material & 3,612 & 3,844 \\
\hline 29 & The material specification used is good and appropriate with technical requirements & 3,542 & 3,846 \\
\hline 30 & Design and material supporting the safety and security & 3,722 & 3,681 \\
\hline 31 & Design and materials in accordance with the ergonomics and comfort & 3,799 & 3,583 \\
\hline 32 & Construction and materials that used is environmentally-friendly & 3,612 & 3,789 \\
\hline 33 & Alternative energy from solar cell sources & 3,482 & 3,680 \\
\hline 34 & Alternative energy from wind sources & 3,393 & 3,578 \\
\hline 35 & No negative area both inside and outside space & 3,916 & 3,840 \\
\hline 36 & Design and material response to disabled, infants, the elderly, and pregnant women & 3,596 & 3,778 \\
\hline 37 & The functioning of natural lighting (sourced sunlight) & 3,897 & 3,820 \\
\hline 38 & The functioning of natural air circulation & 3,880 & 3,752 \\
\hline 39 & View and building orientation toward the wind and the sun direction & 3,892 & 3,840 \\
\hline
\end{tabular}




\begin{tabular}{|c|c|c|c|}
\hline 40 & Space organizations and direction according to architectural standards & 3,979 & 3,912 \\
\hline 41 & There is a distinction between male and female space & 3,624 & 3,771 \\
\hline 42 & Bathroom direction was not facing the Qibla & 3,524 & 3,717 \\
\hline 43 & The placement of the bathroom was hidden and not easily seen & 3,580 & 3,606 \\
\hline 44 & The using material for space building that cover the aurat & 3,876 & 3,735 \\
\hline 45 & There is space for prayer places & 3,599 & 3,673 \\
\hline
\end{tabular}

Furthermore, the mean score in Table 6 are plotted into the importance classification diagram that has four quadrants with a total mean score for User Importance Level/TK $(\bar{Y})=3,809$ and User Satisfaction/KP $(\bar{X})=$ $=3,752$. The resulting plot is shown in Figure 9 .
This analysis stage is called the Importance-Performance Analysis (IPA). The classification of service factors in the four quadrants in the classification diagram of importance-satisfaction (Figure 9) are shown in Table 8.

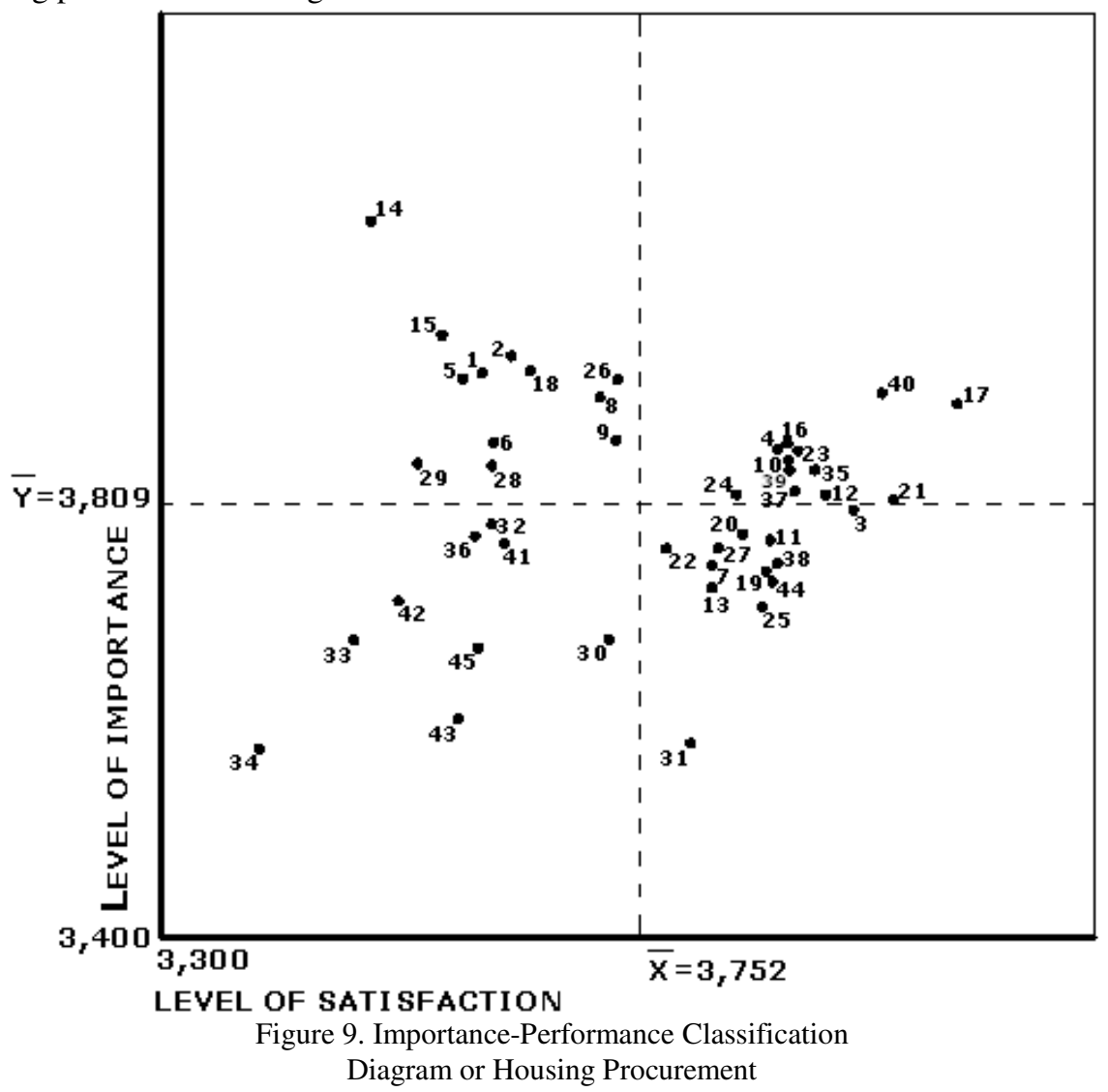

Table 8. Improvement priority level of housing procurement service

\begin{tabular}{lll}
\hline \multicolumn{2}{l}{ Quadrant } & Service Factors Notation \\
\hline A & : High priority & $1,2,5,6,8,9,14,15,18,26,28,29$ \\
B & : Good & $4,10,12,16,17,21,23,24,35,37,39,40$ \\
C & : Low Priority & $30,32,33,34,36,41,42,43,45$ \\
D & $:$ excessive & $3,7,11,13,19,20,22,25,27,31,38,44$ \\
\hline
\end{tabular}

From Figure 9 and Table 8, it shows that the service factor are in quadrant A numbering 12 in which five factors that have the highest score of importance level include: The construction process on time as scheduled projects (number 14), Reliability in service throughout the house procurement activities (number 15), Payment system as sharia can be through Islamic banking (number 2), Good performance of construction and nonconstruction materials (no.18), and Clarity in contract and agreement that honest, serious benefits, and shariacompliant (number 1).

E.Quality Function Deployment Result

Step in Quality Function Deployment (QFD) that to determine gap value between User Satisfaction and User expectation like Table 9. From Table 9, it shows that a significant gap value will be used as reference in drafting technical response on the part of the contractor. Here are many technical responses (notation by $\mathrm{R}$ ),

1. Service with sharia system: payment, contract, agreement, and information that is clear and honest (R-1)

2. Service in procurement files and documents are complete and clear (R-2)

3. Guarantee for protection from force majeure condition of (R-3)

4. Guarantee for protection to avoid building damage after construction (R-4)

5. The project construction on time and accordance with schedule (R-5) 
6. Services for housing procurement projects that reliable (R-6)

7. Implement good construction and non-construction materials (R-7)

8. Providing ease for inspection and evaluation in construction (R-8)

9. Provide convenience to coordinate with the developer (R-9)

10. Provide convenience to coordinate with the contractor (R-10)

11. Provide assurance for construction and nonconstruction accordance with lifetime planning ( R11)
12. Provide assurance in good material specifications that appropriate with technical requirements (R-12)

13. Providing innovation in using of alternative energy sources from solar cell and wind (R-13)

14. Provide assurance in good functioning on natural lighting (sourced sun) and natural air circulation (R-14)

15. Provide opportunities for the building layout with the space separation between women and men (R15).

16. Placing bathroom that not easily visible on the building layout (R-16)

17. Applying building spaces material that close the aurat (R-17).

Table 9. Gap Value between User Satisfaction and Expectation in Housing Procurement Project

\begin{tabular}{cccccccc}
\hline \multirow{2}{*}{ Number } & \multicolumn{2}{c}{ Mean Score } & \multirow{2}{*}{ Gap Value } & \multirow{2}{*}{ No } & \multicolumn{2}{c}{ Mean Score } & \multirow{2}{*}{ Gap Value } \\
\cline { 2 - 3 } & KP & HP & & & KP & HP & \\
\hline 1 & 3,603 & 4,024 & $-0,421$ & 24 & 3,842 & 3,905 & $-0,063$ \\
3 & 3,630 & 4,285 & $-0,655$ & 25 & 3,866 & 3,987 & $-0,121$ \\
4 & 3,952 & 3,905 & 0,047 & 26 & 3,730 & 3,993 & $-0,263$ \\
5 & 3,881 & 3,985 & $-0,104$ & 27 & 3,825 & 3,750 & 0,075 \\
6 & 3,585 & 3,887 & $-0,302$ & 28 & 3,612 & 3,914 & $-0,302$ \\
7 & 3,614 & 3,878 & $-0,264$ & 29 & 3,542 & 3,941 & $-0,399$ \\
8 & 3,819 & 3,736 & 0,083 & 30 & 3,722 & 3,692 & 0,030 \\
9 & 3,714 & 3,712 & 0,002 & 31 & 3,799 & 3,708 & 0,091 \\
10 & 3,729 & 3,678 & 0,051 & 32 & 3,612 & 3,575 & 0,037 \\
11 & 3,891 & 3,755 & 0,136 & 33 & 3,482 & 3,625 & $-0,143$ \\
12 & 3,874 & 4,037 & $-0,163$ & 34 & 3,393 & 3,655 & $-0,262$ \\
13 & 3,926 & 3,911 & 0,015 & 35 & 3,916 & 3,675 & 0,241 \\
14 & 3,819 & 3,811 & 0,008 & 36 & 3,596 & 3,661 & $-0,065$ \\
15 & 3,498 & 4,534 & $-1,036$ & 37 & 3,897 & 4,014 & $-0,117$ \\
16 & 3,565 & 4,338 & $-0,773$ & 38 & 3,880 & 4,077 & $-0,197$ \\
17 & 3,890 & 3,822 & 0,068 & 39 & 3,892 & 3,782 & 0,110 \\
18 & 4,050 & 3,849 & 0,201 & 40 & 3,979 & 3,675 & 0,304 \\
19 & 3,648 & 3,884 & $-0,236$ & 41 & 3,624 & 3,824 & $-0,200$ \\
20 & 3,870 & 3,825 & 0,045 & 42 & 3,524 & 3,605 & $-0,081$ \\
21 & 3,848 & 3,807 & 0,041 & 43 & 3,580 & 3,725 & $-0,145$ \\
22 & 3,990 & 3,915 & 0,075 & 44 & 3,876 & 3,982 & $-0,106$ \\
23 & 3,776 & 3,821 & $-0,045$ & 45 & 3,599 & 3,658 & $-0,059$ \\
\hline
\end{tabular}

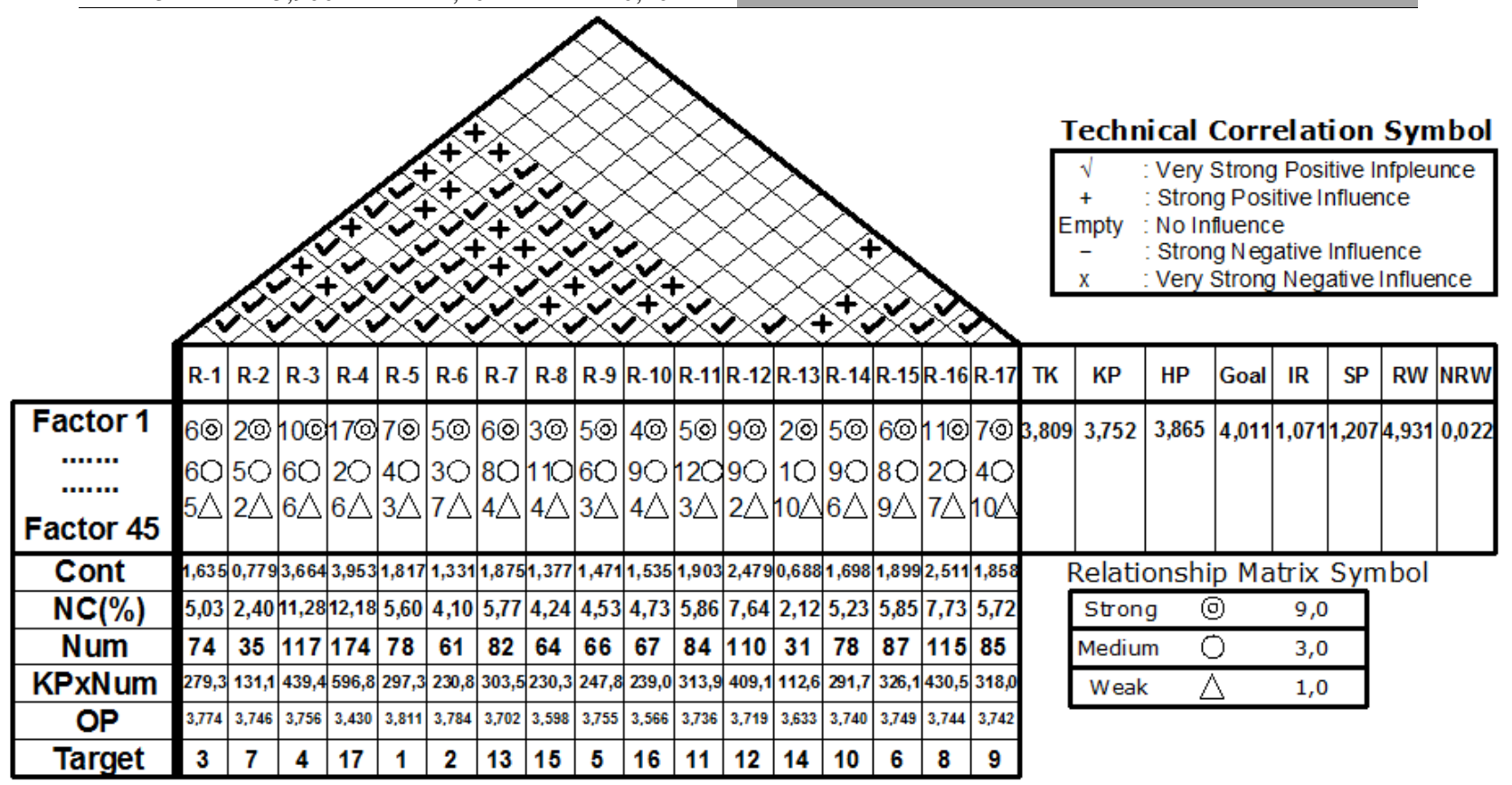

Figure 10. House of Quality for determination target to enhance housing procurement project service 
The seventeen technical responses are included in the House of Quality (HOQ) to determine the target of increasing the housing procurement services by the contractor. Figure 10 is the House of Quality for the determination of the target. The House of Quality can determine the sequence of the target of increasing procurement of housing by the developer and the contractor based on the value of Own Performance (OP). OP value is higher, the higher the ranking target. Results targeting based OP shown in Table 10. From Table 10 it appears that the five technical response to the level of the highest targets include the timely implementation of construction projects on schedule (R-5). These results have strong similarities with the results of IPA in which factors such as The construction process on time as scheduled projects (number 14). These results indicate that the factors of performance and technical responses have a strong correlation and analysis results further demonstrate the level of validity and reliability.

Table 10. Target Determination on Service Enhancement for Housing Procurement Project

\begin{tabular}{clr}
\hline Target & Respon Teknis & OP \\
\hline 1 & The project construction on time and accordance with schedule (R-5) & 3,811 \\
2 & Services for housing procurement projects that reliable (R-6) & 3,784 \\
3 & Service with sharia system: payment, contract, agreement, and information that is clear and honest (R-1) & 3,774 \\
4 & Guarantee for protection from force majeure condition of (R-3) & 3,756 \\
5 & Provide convenience to coordinate with the developer (R-9) & 3,755 \\
6 & Provide opportunities for the building layout with the space separation between women and men (R-15). & 3,749 \\
7 & Service in procurement files and documents are complete and clear (R-2) & 3,746 \\
8 & Placing bathroom that not easily visible on the building layout (R-16) & 3,744 \\
9 & Applying building spaces material that close the aurat (R-17) & 3,742 \\
10 & Provide assurance in good functioning on natural lighting (sourced sun) and natural air circulation (R-14) & 3,740 \\
11 & Provide assurance for construction and non-construction accordance with lifetime planning (R-11) & 3,736 \\
12 & Provide assurance in good material specifications that appropriate with technical requirements (R-12) & 3,719 \\
13 & Implement good construction and non-construction materials (R-7) & 3,702 \\
14 & Providing innovation in using of alternative energy sources from solar cell and wind (R-13) & 3,633 \\
15 & Providing ease for inspection and evaluation in construction (R-8) & 3,598 \\
16 & Provide convenience to coordinate with the contractor (R-10) & 3,566 \\
17 & Guarantee for protection to avoid building damage after construction (R-4) & 3,430 \\
\hline
\end{tabular}

F.Affinity Diagram for Project Service Quality

Enhancement

Affinity Diagram is a diagram illustrating a classification of variables that are the focus of research. Improvement priorities for housing procurement services obtained from the IPA stages with reference to the importance classification diagram, while the service improvement target for future that resulted from the QFD stages with reference to the house of quality. The next step to make affinity diagram consisting of a combination improvement priority $(\mathrm{P})$ and of the target (T) to increase service of housing procurement projects shown in Figure 11.

\section{CONCLUSION}

The evaluation of housing procurement services to consider users (clients) perception promote the performance principle of construction projects in various aspects including Islamic principles and green building. Preliminary survey acquired 8 service factor based on the principles of sharia construction management and green building is Assurance, Responsibility and Reliability, Performance, Aesthetics, Easiness, Durability, Ecofriendly, and Islamic Design. The eight factors describe that the Responsiveness and Reliability factors has mean score highest of need level. The continuation survey for IPA acquire 45 service factors which The construction finish on time as scheduled project has highest scores of importance level. While the analysis stage QFD obtained 17 technical responses with The project construction on time and accordance with schedule has the highest score for service improvement targets.
Multiple linear regression analysis obtained the influence of eight service factors that is very strong to the service quality of housing procurement. The two analysis showed that eight service factors that are research variables have an important influence to service quality of housing project in Griya Amorf Sawojajar Malang.

\section{REFERENCES}

Abusinn, Ahmad Ibrahim. 2008. A Sharia Management: A Historical Study and contemporer. Jakarta: Raja Grafindo.

Ambrosius. 2011. A prediction Model for Project Success with Post-Qualification Document belonging Contractor (Case Study in Kupang City North East Nusa). Civil Engineering Journal/Volume 5, 1 - 2011-ISSN 1978-5658 Brawijaya University of Malang.

Andriati, A.H and Nurus, U.S. 2007. Building Materials Standards Application in Housing Infrastructure Development. Standardization Journal. Vol. 9. No. 3. Puslitbang BSN.

Ervianto, Wulfram. 2013. Study of Road Infrastructure Green Construction Factors According to Greenroad Rating System. Proceedings of the National Conference of Civil Engineering 7. University of Sebelas Maret (UNS) Surakarta.

Hafidhuddin, Didi, and Tanjung, Hendri. 2005. Sharia Management in Practice. Jakarta: Gema Insani.

Hardiman, Gagoek. 2006. Building comfort and cecurity that is overview from site, material, and utilities condition. Journal of Design and Construction Vo.5 No. 1, June 2006. Diponegoro University Semarang

Herina, Silvia F. Study of Standards Application: Planning Procedures for Concrete Structure of Building Implementation in Indonesia. Standardization Journal. Vol. 9. No. 1. Puslitbang BSN. 
Assurance:

- Services with sharia system: payment, contract, agreement, and information that is clear and honest ( $\mathrm{P}$ $\& \mathrm{~T}$ )

- Guarantee protection from force majeure condition (P $\& \mathrm{~T}$ )

- Services providing document and file of housing procurement are complete and clear $(\mathrm{T})$

- Guarantees protection avoid buildings damage after construction (P \& T)

\section{Easiness:}

- Easy to coordinate with the developer (T)

- Easy to conducting inspections and evaluation of construction

- Easy to coordinate with the contractor (P \& T)

\section{Durability:}

- Provide assurance for construction and nonconstruction accordance with lifetime planning (P \& T)

- Provide assurance in good material specifications that appropriate with technical requirements $(\mathrm{T})$

\section{Performance: \\ - Implement good construction and non-construction materials (P \& T)}

Responsibility and Reliability:

- The construction finish on time as scheduled project (P \& T)

- Services on housing procurement projects that reliable (T)

- Reliability in service throughout the house procurement activity (P)

- Developers who give attention to all client complaints $(\mathrm{P})$

- Developers responsive to client problems (P)

\section{Islamic Design:}

- Provide opportunities for the building layout with the space separation between women and men (T)

- Placing bathroom that not easily visible on the building layout (T)

- Applying building spaces material that close the aurat $(\mathrm{T})$

\section{Eco-friendly:}

- Provide assurance in good functioning on natural lighting (sourced sun) and natural air circulation $(\mathrm{T})$

- Providing innovation in using of alternative energy sources from solar cell and wind $(\mathrm{T})$

Figure 11. Affinity Diagram of Improvement Priority and Target for Housing Procurement Project

[1] Huda, Miftahul. 2013. Analisis of Important Factors Evaluation Criteria for Green Building. The International Journal of Engineering And Science (IJES) Volume 2 Issue 12 Pages 41-47 ISSN (e): $2319-1813$ ISSN (p): $2319-1805$.

[2] Komalasari, Rahayu Indah. 2014. Green Building Assessment Based on Energy Efficiency and Conservation (EEC) Category at Pascasarjana B Building Diponegoro University of Semarang. American Journal of Energy Research, 2014, Vol. 2, No. 2, 42-46.

[3] Mardiansyah, Yudi. 2012. Evaluation of Drainage Systems of the North Sumatra University Campus. Department of Civil Engineering, North Sumatra University, Medan.

[4] Muzammil, Rizki. 2014. Application of Infiltration Biopori as an alternative to minimize flood in Ciledug Indah Housing Region I. Community Service Program of Esa Unggul University, Jakarta.

[5] Nuryani, Irma. 2006. Identification of the House Governmental Procurement By Low-Income Communities in the District Tembalang Semarang. City \& Regional Planning Department, Faculty of Engineering, Diponegoro University of Semarang.

[6] Priyo, Mandiyo. 2013. Analysis of Special Contractor. National Conference of Civil Engineering 7 (Context 7) University of Sebelas Maret (UNS) Surakarta.

[7] Rauf, Nurhayati. 2002. Application of Quality Function Deployment in Improving Public Transport Terminal Services Quality: A Case Study In Public Transport Sungguminasa Gowa Terminal-Indonesia. Postgraduate of Industrial Engineering of Sepuluh Nopember Institute of Technology, Surabaya Indonesia.

[8] Sedayu, Agung. 2010. Analysis of Sharia Construction Project Cost in Indonesia in Islamic Perspective. Journal of Islamic Architecture. Volume
1 Issue.1 June 2010. ISSN 2086-2636. Department of Architecture-UIN Maulana Malik Ibrahim Malang.

[9] Sedayu, Agung. 2015. Factors description in the Performance development of Green Terminal Hamid Rusdi Malang. Proceedings of the National Seminar on Regional Infrastructure Technology Application (ATPW) Civil Engineering ITS Surabaya.

[10] Siddiqi, Muhammad Nejatullah. 1991. Economic Activity in Islam. Jakarta : Bumi Aksara.

[11] Spekkink, Dik. 2005. Performance Based Design of Buildings, Final Domain Report.. CIBdf. Netherland.

[12] Sugiyono, 2009. Statistic for Research. Bandung: Alfabeta press

[13] Syahrozi. 2013. Thermal Comfort In Wide Span Building Landscape (Case Study Palangkaraya Hall, Palangkaraya University). Journal of Architectural Perspectives Vol. 82 ISSN 1907-8536

[14] Wijaya, Tony. (2011). Services Management Quality: SERVQUAL Design, QFD and Kano with Application in Research Cases. Index, JakartaIndonesia.

[15] Wulandari, Anis. 2010. Initiating the concept of Good Corporate Governance in Islamic Construction. Pamator, Volume 3, Number 1, April 2010 